\title{
Textural and geochemical analysis of a pumice polisher with grooves from the Magdalenian site of Duruthy (Sorde, Landes, France)
}

Morgane Dachary, Catherine Deniel, Frédéric Plassard, Pierre Boivin and Jean-Luc Devidal

\section{(2) OpenEdition}

\section{Journals}

Electronic version

URL: http://journals.openedition.org/paleo/2460

DOI: $10.4000 /$ paleo.2460

ISSN: 2101-0420

Publisher

SAMRA

\section{Printed version}

Date of publication: 15 December 2012

Number of pages: $315-322$

ISSN: $1145-3370$

\section{Electronic reference}

Morgane Dachary, Catherine Deniel, Frédéric Plassard, Pierre Boivin and Jean-Luc Devidal, «Textural and geochemical analysis of a pumice polisher with grooves from the Magdalenian site of Duruthy (Sorde, Landes, France) », PALEO [Online], 23 | 2012, Online since 07 May 2013, connection on 28 July 2020. URL : http://journals.openedition.org/paleo/2460 ; DOI : https://doi.org/10.4000/paleo.2460

This text was automatically generated on 28 July 2020.

\section{c)}

PALEO est mis à disposition selon les termes de la licence Creative Commons Attribution - Pas d'Utilisation Commerciale - Pas de Modification 4.0 International. 


\title{
Textural and geochemical analysis of a pumice polisher with grooves from the Magdalenian site of Duruthy (Sorde, Landes, France)
}

\author{
Morgane Dachary, Catherine Deniel, Frédéric Plassard, Pierre Boivin and \\ Jean-Luc Devidal
}

\begin{abstract}
In the literature concerning the Magdalenian, it is not uncommon to come across references to grooved polishers or abraders. These objects with grooves of varying depth drew the attention of excavators at an early date and were described as polishers for working bone or antler at La Madeleine (Capitan and Peyrony 1928), and Les Combarelles (Rivière 1894), for example. These polishers are generally in soft sandstone although other raw materials, such as pumice stone, were used occasionally. Following the discovery of a possible pumice polisher at the site of Duruthy (Sorde, Landes), a textural and geochemical analysis of the rock was carried out. This analysis confirmed the nature of the pumice stone and made it possible to advance a hypothesis concerning the provenance of the stone. At the same time, an inventory of comparable pieces was established using bibliographical sources. This ongoing research was cofinanced by the Ministry for Culture and the Landes General Council. This paper presents a review of the work carried out so far.
\end{abstract}

\section{1 - Inventory of grooved pumice polishers}

The first mention of a grooved pumice polisher in the literature occurs in 1873, reported by E. Piette: "I found a pumice stone in the cavern which had been used to polish needles and awls. This stone appears to come from volcanic rocks at Agde". (Piette 1873 - p. 413). Later, E. Passemard also documents polishers at Isturitz: "There are fragments of pumice stone used to sharpen bone points". (Passemard 1944 - p. 45 and Pl. XX). Another example is described on the Spanish side of the site of Aitzbitarte 
IV (fig. 1) by J.-M. de Barandiaran (1965), who published a drawing of a pumice polisher with grooves and a perforation. Lastly, the site of Bourrouilla at Arancou, yielded a comparable piece, which is not however perforated. This piece was discovered in the spoil of an illicit excavation (fig. 2), and was published by F.-X. Chauvière (Chauvière in Chauchat et al. 1999).

3 Thus, in the current state of our research, the corpus of grooved polishers in pumice stone is limited (tab. 1), as only five sites are represented. With the exception of Isturitz, each site has only yielded one example. Isturitz thus appears to be unique, but it will be necessary to study the material in order to validate the vague mention of these pieces by E. Passemard. It is noteworthy that all the documented sites are concentrated in the western half of the Pyrenees.

Lastly, the chronostratigraphic data associated with these objects are very limited. None of the pieces are from a recently excavated site with a detailed stratigraphy. However, all of them were discovered in sites yielding Middle and/or Upper Magdalenian levels, which could suggest that the pumice stones used for these objects could have the same provenance.

Figure 1 - Aitzbitarte IV. Pumice stone polisher with grooves. (after Barandiaran 1965).

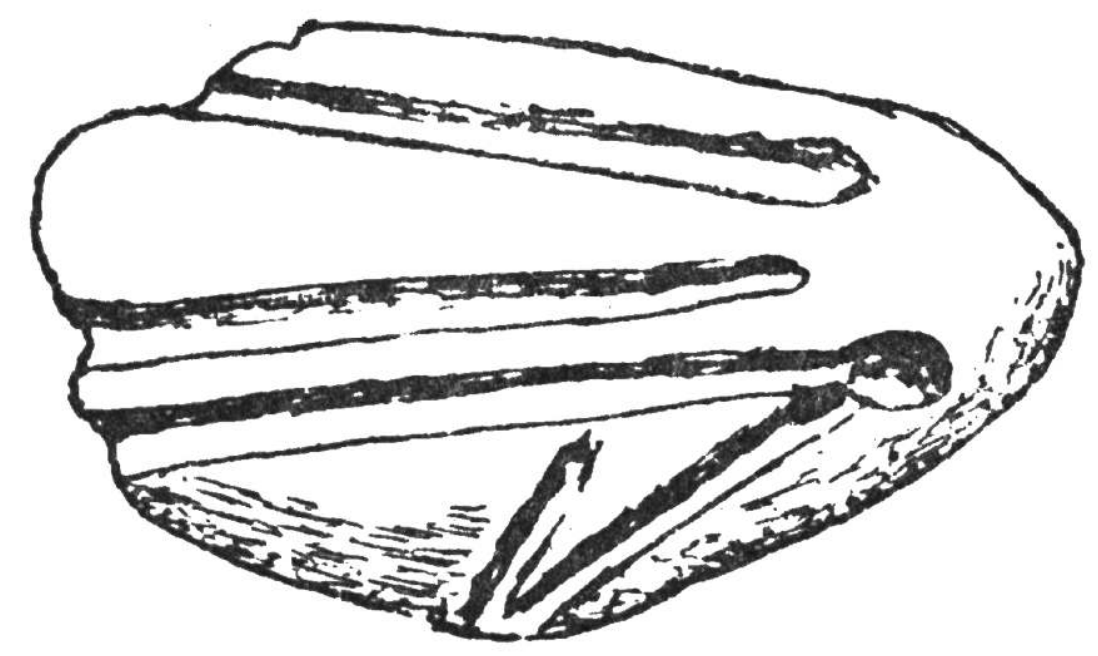

0

$3 \mathrm{~cm}$ 
Figure 2 - Arancou. Pumice stone polisher with grooves. (Drawing F.-X. Chauvière and photo F. Plassard).

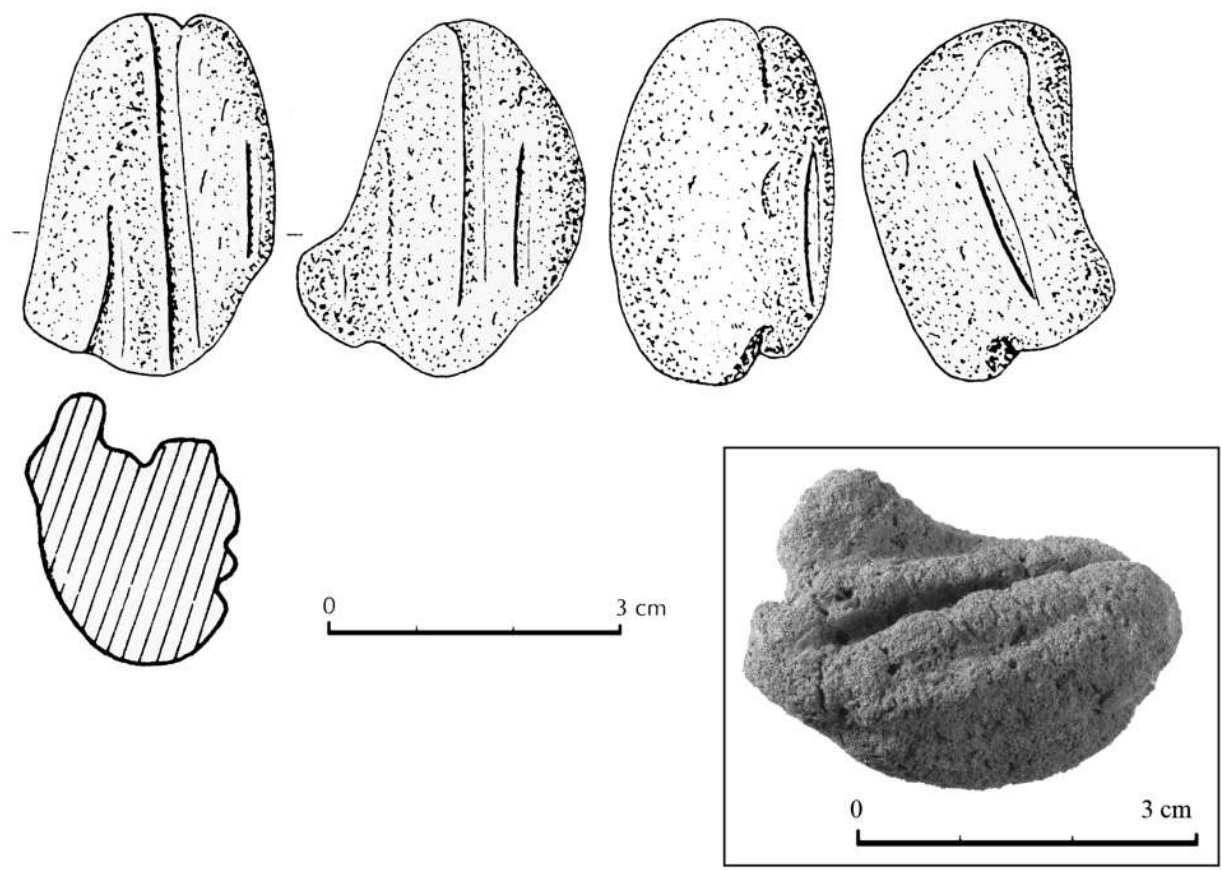

Table 1 - List of the sites with pumice stone polishers with grooves.

\begin{tabular}{l|l|l|l} 
Site & Stratigraphie & Description & Références bibliographiques \\
\hline \hline Aitzbitarte IV & $\begin{array}{l}\text { Couche IV "tierra } \\
\text { oscurra" }\end{array}$ & $\begin{array}{l}\text { Polissoir à rainures avec trou de } \\
\text { suspension }\end{array}$ & Barandiaran (de) 1965 \\
\hline Arancou & $\begin{array}{l}\text { Fouille } \\
\text { clandestine }\end{array}$ & Polissoir à rainures & $\begin{array}{l}\text { Chauvière in Chauchat } \\
\text { et al. 1999 }\end{array}$ \\
\hline Duruthy & Remanié & $\begin{array}{l}\text { Polissoir à rainures avec trou de } \\
\text { suspension }\end{array}$ & Inédit \\
\hline Gourdan & $\begin{array}{l}\text { "assises } \\
\text { représentant } \\
\text { l'Age du renne" }\end{array}$ & $\begin{array}{l}\text { "une pierre ponce qui leur avait } \\
\text { servi à polir des aiguilles et des } \\
\text { poinçons" }\end{array}$ & Piette 1873 \\
\hline Isturitz & Couche E & $\begin{array}{l}\text { "des fragments de pierre ponce } \\
\text { utilisés pour l'affütage des pointes } \\
\text { osseuses" }\end{array}$ & Passemard 1944
\end{tabular}

\section{2 - The Duruthy polisher}

5 The reassessment of the material from the Duruthy rock-shelter by one of us (MD), led to the identification of several grooved polishers (fig. 3). These had initially been considered as being in sandstone (Arambourou 1978), a tender, not very dense and frequently altered raw material. Nonetheless, one of these polishers presents significantly different characteristics (greyer colour, vitreous flakePenn Libraries2013-04-30T17:07:00, high porosity), and lower densityPenn Libraries2013-04-30T17:07:00 than those in sandstone, which supports the pumice 
stone hypothesis (fig. 4). Moreover, it bears a biconical perforation similar to the suspension hole described at Aitzbitarte IV.

Unfortunately, this polisher from Duruthy, discovered during the R. Arambourou excavations between 1959 and 1984, was found in reworkedPenn Libraries2013-04-30T17:07:00 sediments and is thus of unknown stratigraphic provenance. However, it is noteworthy that the other grooved polishers (in sandstone) with stratigraphic attributions are from layers 3 and 4, and are respectively attributed to the Upper and Middle Magdalenian.

7 In order to determine the nature of this material and to attempt to discover its provenance, a textural and geochemical analysis was carried out at the Magma and Volcano Laboratory at Clermont-Ferrand (UMR 6524 CNRS).

Figure 3 - Duruthy. Sandstone polisher. (๑ F. Plassard).

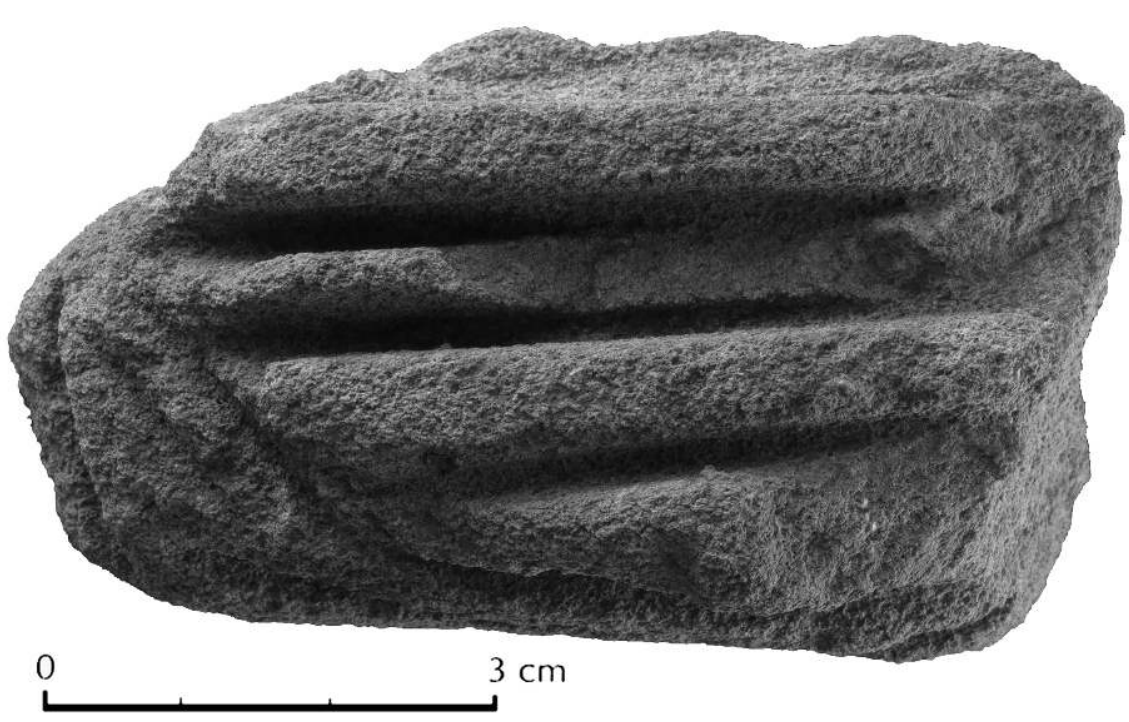

\section{1 - Texture and petrology of the Duruthy polisher}

\subsection{1 - Results of the macroscopic and stereoscopic analysis of the sample}

Although some sedimentary rocks, altered by secondary processes involving preferential dissolution, are as porous as this polisher, it is rare to come across rocks with such low density. Indeed, low density is characteristic of certain volcanic rocks called pumice, with a very specific composition.

We benefitted from the presence of a small, naturally detached fragment of the polisher which was used to conduct further investigations and stereoscopic analysis. The two photographs (fig. 5) illustrate the high porosity of the Duruthy stone polisher. The transparent zones visible on the photographs evoke glass which appears to form the walls of the vesicles. These two observations support the hypothesis that the raw material used for this polisher is probably not a sedimentary rock, but appears to be volcanic pumice stone. 
2.1.2 - Microtexture of the Duruthy polisher using Scanning Electron Microscopy (SEM) imagery

10 The use of scanning electron microscopy enabled us to observe the microtexture of the sample.

11 In figure 6a, the walls of the vesicles observed with the stereomicroscope are clearly visible in detail. Figure $6 \mathrm{~b}$ presents a detail of these walls, where dissolution figures Penn Libraries2013-04-30T17:07:00and small rod crystals are clearly visible.

12 Figure $6 \mathrm{c}$ shows that these rods are associated with the walls and are thus an integral part of the analyzed rock. Indeed, these rods are intersected by the dissolution figures observed on the walls.

\section{2- Geochemical composition of the polisher}

\subsection{1 - Qualitative determination of the geochemical composition using a Scanning electron microscope (SEM) with energy-dispersive X-ray spectroscopy} (EDS)

13 In order to ascertain that the polisher is made of volcanic rock and not sedimentary rock (such as sandstone with a porous structure), we first carried out a qualitative, but not a quantitative determination of the chemical composition of the sample. We chose this qualitative approach as it is totally nondestructive.

The wall of the vesicles visible in the SEM photos was thus analyzed with a scanning electron microscope with a chemical microanalysis system employing dispersive energy (EDS).

The result of the analysis revealed that the vesicle walls are made up of siliceous glass, thereby confirming that the polisher is in volcanic, and probably rhyolitic rock.

Figure 4 - Duruthy. Pumice stone polisher with grooves. (๑ F. Plassard).

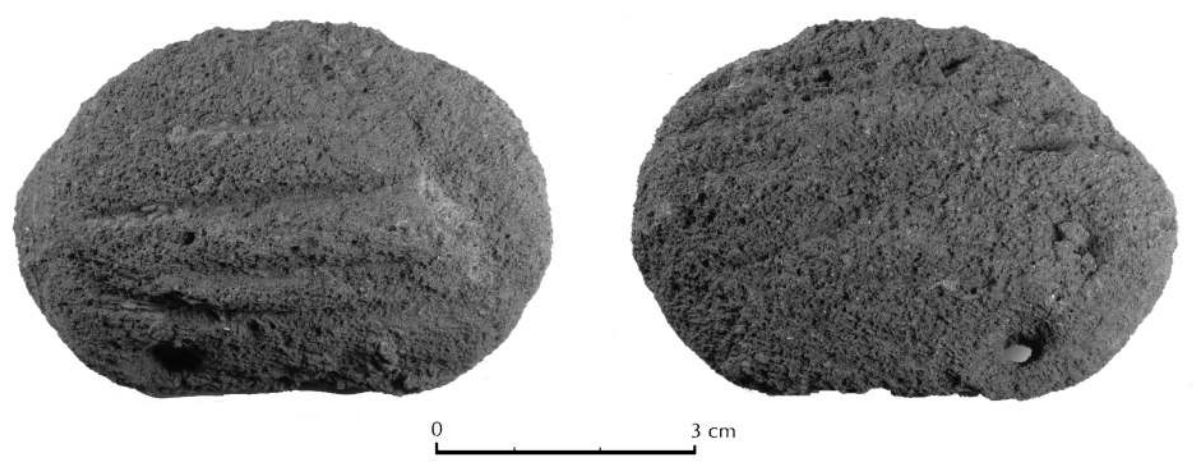


Figure 5 - Duruthy. Fragment of the polisher using binocular magnifying glass. (๑ P. Boivin).

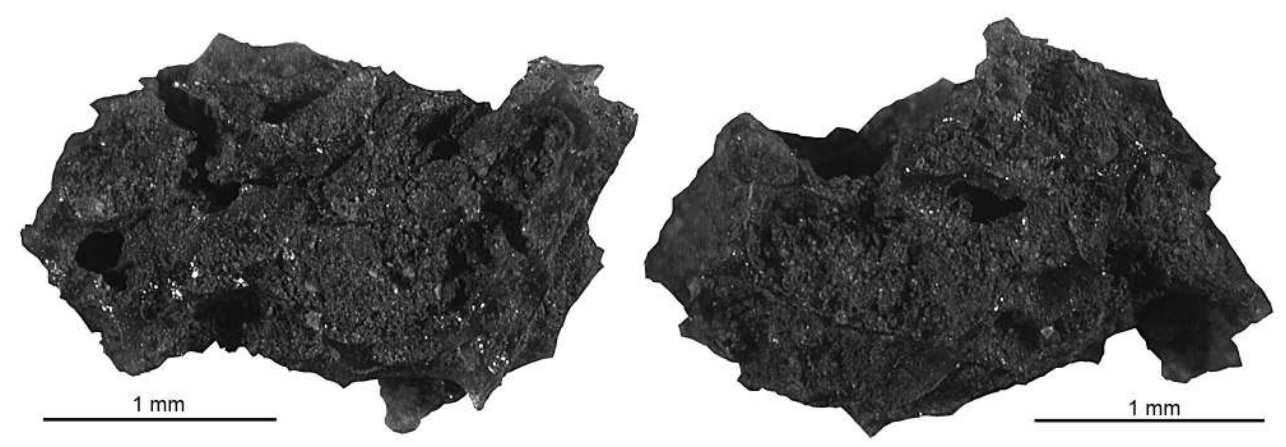

Figure 6 - Duruthy. SEM image of the fragment of polisher. (๑ SEM laboratory).

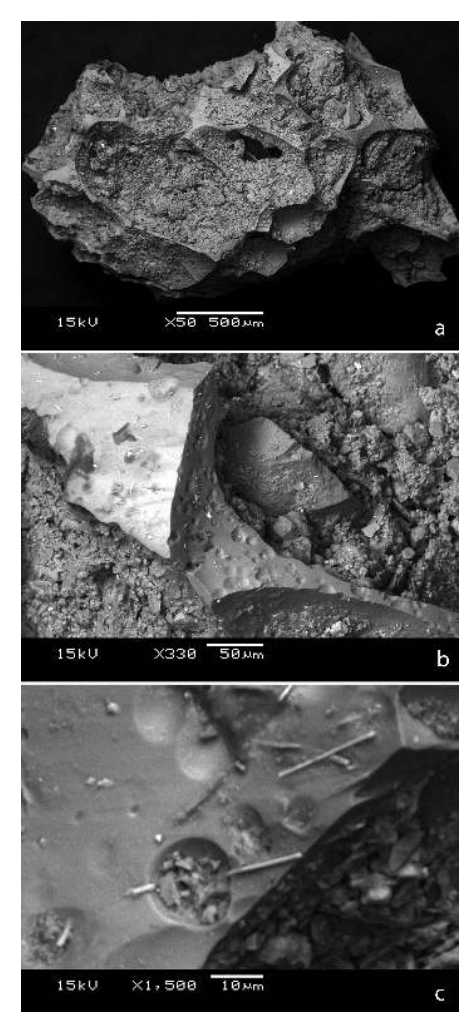

\subsection{2 - Accurate determination of the geochemical composition with electron microprobe analysis}

16 We then obtained the authorization to work freely on the tiny broken fragment of the polisher, allowing us to attain a more accurate analysis of its geochemical composition. This fragment was thus incorporated in a resin base and then abraded and polished before taking quantitative electron microprobe readings (WDS Cameca SX100 of the UMR 6524 CNRS). These measurements were carried out with an acceleration voltage of $15 \mathrm{kV}$. A low current intensity ( $8 \mathrm{nA}$ or even $4 \mathrm{nA}$ ) and a defocused beam (diameter of $20 \mathrm{~mm}$ ) were used in order to minimize the $\mathrm{Na}$ losses, inherent to this type of measurement. Eight ad hoc analyses were carried out in this way on the vesicle walls and one analysis on the associated crystal rods described in section 2.1.2. At the same time, the international standard A99 (basaltic glass from Kilauea, Hawaii, Jarosewich et 
al. 1979; Thornber et al. 2002) was measured seven times in order to provide an external verification of the exact and reproducible nature of these readings.

The individual results (tab. 2) are very coherent (cf. standard deviations of averages). In addition, the values obtained with the standard are indistinguishable (within the limit of the standard deviations) from those in the literature and from those previously obtained at the UMR 6524 using the same instrument (Oladottir et al. 2011), thus underlining the reliability of these results. Even the $\mathrm{Na}_{2} \mathrm{O}$, frequently subject to higher errors than other oxides because of its volatility during measurements (cf. a slightly higher standard deviation), is accurately determined, as indicated by the results on the standard A99. These very accurate microprobe results confirm that the material composing the vesicle walls is rhyolitic glass.

In addition, the composition of the small rod crystals, and notably the $\mathrm{Fe}$ and $\mathrm{Mg}$ percentages, are comparable to those observed in the pyroxenes of differentiated volcanic rocks. Given the nature of the rock, the enrichment in Fe and $\mathrm{Mg}$ and the form of the crystals, these rods appear to be small pyroxene crystals.

Table 2 - Duruthy. Electron microprobe analyses of the walls of the vesicles of the polisher and of the associated acicular crystals (pyroxene). $n$ denotes the number of analyses used to calculate the means. * Lower quality analysis compared to the analyses on the vesicle walls because of the small size of the crystals.

\begin{tabular}{|c|c|c|c|c|c|c|c|c|c|c|c|c|}
\hline \multicolumn{2}{|c|}{ Standard international A99 } & \multicolumn{10}{|c|}{ Oxydes \% (poids) } & \\
\hline \multicolumn{2}{|c|}{$\mathrm{n}^{\circ}$ d'analyse } & $\mathrm{SiO}_{2}$ & $\mathrm{TiO}_{2}$ & $\mathrm{Al}_{2} \mathrm{O}_{3}$ & $\mathrm{FeO}$ & $\mathrm{MnO}$ & $\mathrm{MgO}$ & $\mathrm{CaO}$ & $\mathrm{Na}_{2} \mathrm{O}$ & $\mathrm{K}_{2} \mathrm{O}$ & $\mathrm{P}_{2} \mathrm{O}_{5}$ & Total \\
\hline \multicolumn{2}{|c|}{1} & 51,34 & 4,13 & 12,65 & 13,11 & 0,28 & 5,08 & 9,02 & 2,64 & 0,85 & 0,50 & 99,61 \\
\hline \multicolumn{2}{|l|}{2} & 51,37 & 4,08 & 12,84 & 13,50 & 0.20 & 5,04 & 9,20 & 2,77 & 0,84 & 0,44 & 100,27 \\
\hline \multicolumn{2}{|l|}{3} & 50,78 & 4,01 & 12,82 & 12,95 & 0,20 & 5,00 & 9,10 & 2,68 & 0,88 & 0,48 & 98,91 \\
\hline \multicolumn{2}{|l|}{4} & 50,49 & 4,18 & 13,04 & 13,17 & 0,28 & 5,07 & 8,94 & 2.77 & 0,84 & 0,49 & 99,27 \\
\hline \multicolumn{2}{|l|}{5} & 51,24 & 4,15 & 12,60 & 13,67 & 0,23 & 5,04 & 9,26 & 2,68 & 0,83 & 0,53 & 100,24 \\
\hline \multicolumn{2}{|l|}{6} & 51,22 & 4,18 & 12,54 & 13,54 & 0,25 & 5,05 & 9,05 & 2,80 & 0,89 & 0,48 & 99,99 \\
\hline \multicolumn{2}{|l|}{7} & 51,12 & 4,15 & 12,68 & 13,18 & 0,17 & 5,07 & 9,09 & 2,55 & 0,86 & 0,40 & 99,25 \\
\hline \multirow[t]{2}{*}{ Cette étude } & $\begin{array}{c}\text { moyenne } \\
(\mathrm{n}=7)\end{array}$ & 51,08 & 4,13 & 12,74 & 13,30 & 0,23 & 5,05 & 9,09 & 2,70 & 0,86 & 0,47 & 99,65 \\
\hline & ècart-type & 0,33 & 0,06 & 0,17 & 0,27 & 0,04 & 0,03 & 0,11 & 0,09 & 0,02 & 0,04 & 0,53 \\
\hline \multirow{2}{*}{$\begin{array}{l}\text { Oladottir et al. (2011) } \\
\text { (UMR 6524 CNRS) }\end{array}$} & $\begin{array}{l}\text { moyenne } \\
(\mathrm{n}=1536)\end{array}$ & 51,00 & 4,17 & 12,65 & 13,20 & 0,20 & 5,01 & 9,14 & 2,69 & 0,86 & 0,46 & 99,35 \\
\hline & écart-type & 0,54 & 0,06 & 0,15 & 0,29 & 0,07 & 0,09 & 0,09 & 0,11 & 0,02 & 0,02 & \\
\hline $\begin{array}{c}\text { Jarosewich et al. } \\
(1979)\end{array}$ & & 50,94 & 4,06 & 12,49 & 13,30 & 0,15 & 5,08 & 9,30 & 2,66 & 0,82 & 0,38 & 99,18 \\
\hline \multirow[t]{2}{*}{ Thomber et al. (2002) } & $\begin{array}{c}\text { moyenne } \\
(\mathrm{n}=418)\end{array}$ & 51,06 & 3,95 & 12,44 & 13,15 & 0,19 & 5,04 & 9,04 & 2,72 & 0,82 & 0,43 & 98,84 \\
\hline & ècart-type & 0,46 & 0,09 & 0,13 & 0,16 & 0,02 & 0,10 & 0,11 & 0,16 & 0,03 & 0,03 & \\
\hline
\end{tabular}

\begin{tabular}{|c|c|c|c|c|c|c|c|c|c|c|c|c|}
\hline \multirow{2}{*}{$\begin{array}{c}\text { Polissoir de Duruthy } \\
\text { Paroi des vésicules } \\
n^{\circ} \text { d'analyse } \\
\end{array}$} & \multicolumn{10}{|c|}{ Oxydes \% (poids) } & & \multirow{2}{*}{$\begin{array}{c}\text { Caractéristiques } \\
\text { faisceau }\end{array}$} \\
\hline & $\mathrm{SiO}_{2}$ & $\mathrm{TiO}_{2}$ & $\mathrm{Al}_{2} \mathrm{O}_{3}$ & $\mathrm{FeO}$ & $\mathrm{MnO}$ & $\mathrm{MgO}$ & $\mathrm{CaO}$ & $\mathrm{Na}_{2} \mathrm{O}$ & $\mathrm{K}_{2} \mathrm{O}$ & $\mathrm{P}_{2} \mathrm{O}_{5}$ & Total & \\
\hline 1 & 75,66 & 0,18 & 13,32 & 1,21 & 0.12 & 0,02 & 0,77 & 4,35 & 3,99 & 0,00 & 99,64 & $8 \mathrm{nA}, 20 \mu \mathrm{m}$ \\
\hline 2 & 74,87 & 0,18 & 13,58 & 1,15 & 0,09 & 0,01 & 0,87 & 4,83 & 3,83 & 0,07 & 99,49 & $4 \mathrm{nA}, 20 \mu \mathrm{m}$ \\
\hline 3 & 75,06 & 0,18 & 13,54 & 1,24 & 0,12 & 0,03 & 0,75 & 4,22 & 4,02 & 0,10 & 99,25 & $4 \mathrm{nA}, 20 \mu \mathrm{m}$ \\
\hline 4 & 75,10 & 0,15 & 13,45 & 1,12 & 0,10 & 0,05 & 0,76 & 4,44 & 4,01 & 0,00 & 99,18 & $8 \mathrm{nA}, 20 \mu \mathrm{m}$ \\
\hline 5 & 74,99 & 0,17 & 13,62 & 1,30 & 0,04 & 0,05 & 0,77 & 4,35 & 4,02 & 0,08 & 99,39 & $8 \mathrm{nA}, 20 \mu \mathrm{m}$ \\
\hline 6 & 74,80 & 0,17 & 13,74 & 0,94 & 0,06 & 0,02 & 0.75 & 3,98 & 4,07 & 0,00 & 98,53 & $4 \mathrm{nA}, 20 \mu \mathrm{m}$ \\
\hline 7 & 74,45 & 0,20 & 13,67 & 1,00 & 0,00 & 0,00 & 0,77 & 3,99 & 4,00 & 0,00 & 98,09 & $4 \mathrm{nA}, 20 \mu \mathrm{m}$ \\
\hline 8 & 75,50 & 0,17 & 13,25 & 1,31 & 0,07 & 0,04 & 0,76 & 4,22 & 4,02 & 0,01 & 99,35 & $8 \mathrm{nA}, 20 \mu \mathrm{m}$ \\
\hline moyenne $(n=8)$ & 75,05 & 0,18 & 13,52 & 1,16 & 0,08 & 0,03 & 0,78 & 4,30 & 4,00 & 0,03 & 99,11 & \\
\hline écart-type & 0,39 & 0,01 & 0,17 & 0,13 & 0,04 & 0,02 & 0,04 & 0,27 & 0,07 & 0,04 & 0,53 & \\
\hline $\begin{array}{l}\text { Polissoir de Duruthy } \\
\text { Cristaux en baguettes }\end{array}$ & \multicolumn{10}{|c|}{ Oxydes \% (poids) } & & \\
\hline $\mathrm{n}^{\circ}$ d'analyse & $\mathrm{SiO}_{2}$ & $\mathrm{TiO}_{2}$ & $\mathrm{Al}_{2} \mathrm{O}_{3}$ & $\mathrm{FeO}$ & $\mathrm{MnO}$ & $\mathrm{MgO}$ & $\mathrm{CaO}$ & $\mathrm{Na}_{2} \mathrm{O}$ & $\mathrm{K}_{2} \mathrm{O}$ & Total & & \\
\hline & 48,88 & 0,48 & 1,83 & 24,21 & 0,81 & 8,26 & 13,31 & 0,33 & 0,09 & $98,20 *$ & & \\
\hline
\end{tabular}

\section{3 - Conclusion on the nature of the geological material of the grooved polisher from the Duruthy prehistoric site.}

19 The results of these textural, microtextural, petrological and geochemical studies on this tiny polisher fragment prove that it is indeed a volcanic, and not a sedimentary raw material. 
20 Moreover, the quantitative geochemical electron microprobe analyses enable us to specify the petrological nature of the rock in question. It is a rhyolitic pumice, rhyolites being volcanic rocks with the most evolved geochemical composition of the silica saturated series. The prominent vesicles indicate that this rock is the result of an explosive, and not an effusive volcanic eruption.

21 The volcanic origin and the rhyolitic nature of the raw material of the polisher have thus been established.

\section{3 - Reflection on the geographical origin of the rhyolitic pumice of the Duruthy polisher}

Neither the western part of the Pyrenees, nor its Cantabrian extensions, contain any potential source of pumice stone. The discovery of several worked objects in this raw material in different Magdalenian sites in the region thus raises the question of the provenance of this stone.

In 1873, E. Piette advanced the hypothesis that the pumice polisher from Gourdan came from the Cap d'Agde. He brought up the issue to demonstrate that hunter-gatherers during the Age of the Reindeer were nomads (Piette 1873). At present, perspectives have changed, but the provenance of raw materials and the understanding of the territories exploited by hunter-gatherers remain central to Palaeolithic archaeological research.

The Cap d'Agde hypothesis put forward by E. Piette can no longer be retained for the Duruthy polisher as none of the volcanic rocks in this sector are authentic pumice stones. Similarly, there is no correspondence between the geochemical composition of the pumice used for the polisher and that of the Massif Central pumice.

On the other hand, the concentration of sites near the Atlantic coast bearing these objects points towards a coastal provisioning of the raw material through flotation, following a volcanic eruption on an Atlantic or Caribbean island (or even on the American continent?). Up until now, the ongoing assessment of bibliographic data concerning eruptions at the end of the Pleistocene has not identified any major eruptive event that produced raw materials with a similar geochemical signature to that of the Duruthy polisher. This hypothesis has thus not yet been proven, although it seems to be the most likely. It would nonetheless constitute a supplementary but unexpected proof of coastal exploitation by Tardiglacial hunter-gatherers in the southwest of France and the north of Spain (Pétillon 2008; Corchón-Rodriguez and Álvarez-Fernandez 2008). It is noteworthy that similar phenomena have been documented during the Neolithic, in the north of Europe (Scotland, Scandinavia) and more occasionally, in Brittany (Giot 1972).

Moreover, this coastal source of pumice stone would have been available based on rare events, and the conservation of this raw material on the coast would have been shortlived. If analyses from other documented polishers demonstrate the identical nature of the stone from one site to another, this would provide a significant element for proving the relative contemporaneity of the different sites.

27 At this stage, our project on polishers in pumice stone is still ongoing. Among the objects identified in the literature, only those from Arancou and Duruthy were directly studied and only the Duruthy polisher was subjected to geochemical analyses in order 
to identify the major elements. In the future, the multiplication of geochemical analyses (in order to identify both major and trace elements, indispensable for reliably identifying the volcanic source of the raw material) on other objects, more bibliographical research and the assessment of existing geochemical data from Atlantic volcanic events at the end of the Pleistocene will enable us to address pending questions.

\section{BIBLIOGRAPHY}

ARAMBOUROU R. (dir.) 1978 - Le gisement préhistorique de Duruthy à Sorde-l'Abbaye (Landes), Société Préhistorique Française, Mémoire 13, 158 p.

BARANDIARAN J.-M. (de) 1965 - Excavaciones en la caverna de Aitzbitarte IV, Noticiario arqueologico hispanico, tome VII, p. 35-48

CAPITAN L., PEYRONY D. 1928 - La Madeleine : son gisement, ses industries et ses œuvres d'art, Publications de l'Institut International d'Anthropologie, Paris: Librairie Nourry, 125 p., 70 fig., 19 pl.

CHAUCHAT CL., FONTUGNE M., HATTE CH., DACHARY M., BONNISSENT D., CHAUVIÈRE F.-X., ROUSSOT A., FRITZ C., FOSSE PH., EASTHAM A., MARTIN H., LE GALL O., GAMBIER D. 1999 L'habitat Magdalénien de la grotte Bourrouilla à Arancou (Pyrénées Atlantiques). Gallia Préhistoire, tome 41, p. 1-151.

CORCHÓN-RODRÍGUEZ M.-S., ÁLVAREZ-FERNÁNDEZ E. 2008 - Nuevas evidencias de restos de mamíferos marinos en el Magdaleniense : los datos de La Cueva de Las Caldas (Asturias, España). Munibe, 59 p. 47-66

GIOT P.-R. 1972 - La pierre ponce des sites préhistoriques de Bretagne. Bulletin de la Société Préhistorique française, tome 69 n5, p. 159-160.

JAROSEWICH E., NELEN J.A., BORBERG J.A. 1979 - Electron microprobe reference samples for mineral analysis. In: Fudali R.F. (ed.) Smithsonian Institution Contributions to the Earth Sciences $n^{\circ} 22$. Smithsonian Institution Press, p. 68-72.

OLADOTTIR B.A., SIGMARSSON O., LARSEN G., DEVIDAL J.-L. 2011 - Provenance of basaltic tephra from Vatnajökull subglacial volcanoes, Iceland, as determined by major- and trace-element analyses. The Holocene 21(7), p. 1037-1048.

PASSEMARD E. 1944 - La caverne d'Isturitz en pays basque, La Préhistoire, 9, p. 7-95.

PÉTILLON J.-M. 2008 - First evidence of a whale-bone industry in the western European Upper Paleolithic: Magdalenian artifacts from Isturitz (Pyrénées-Atlantiques, France). Journal of Human Evolution 54, 720-726.

PIETTE E. 1873 - Sur la grotte de Gourdan, sur la lacune que plusieurs auteurs placent entre l'âge du renne et celui de la pierre polie, et sur l'art paléolithique dans ses rapports avec l'art gaulois. Bulletin de la Société d'anthropologie de Paris, II Série. tome 8, p. 384-425 
THORNBER C.R., SHERROD D.R., SIEMS D.R., HELIKER C.C., MEEKER G.P., OSCARSSON R.L. et al. 2002 - Whole rock and glass major-element geochemistry of Kilauea volcano, Hawaii, near-vent eruptive products: september 1994 through september 2001. USGS, Open file report p. 2-17.

RIVIÈRE E. 1894 - Nouvelles recherches anthropologiques et paléontologiques dans la Dordogne. Association française pour l'avancement des sciences, $23^{\circ}$ session, Caen. p. 709-722.

\section{ABSTRACTS}

Magdalenian archaeological sites often contain grooved polishers used to polish other implements (for example, Capitan and Peyrony 1928). These objects are generally made from sandstone but a few are made from pumice. Bibliographic research revealed that only four sites have yielded pumice stone polishers (fig. 1, fig. 2, tab. 1). These are the sites of Gourdan (Piette 1873), Isturitz (Passemard 1944), Aitzbitarte IV (Barandiaran 1965) and Arancou (Chauchat et al. 1999). Several polishers were found in the Duruthy rock-shelter, Sorde-L'abbaye, Landes. Most of these polishers are in sandstone (fig. 3) but one of them is different and has the appearance of pumice (fig. 4). The textural study and geochemical analysis (fig. 5, fig. 6, tab. 2) of this polisher indicate that it was made from rhyolitic pumice. The geochemical characteristics of this material indicate that it is not a product of French volcanism. The fact that all the sites where pumice polishers were found are located near the Atlantic Ocean suggests that floated pumices may have been collected along the ocean shores. Such rhyolitic pumices could have been produced during the eruption of a volcano on an island in the Atlantic Ocean. Although we have not yet identified the volcano responsible for this eruption, this remains the most likely hypothesis. In this respect, these artefacts offer a new approach to the study of the exploitation of the littoral zone by the last Palaeolithic hunters in southwest France and northern Spain.

\section{INDEX}

Keywords: Magdalenian, geochemical analysis, rhyolite

\section{AUTHORS}

\section{MORGANE DACHARY}

UMR 5608 - TRACES. Université Toulouse-II-le Mirail. Maison de la recherche, 5 allée Antonio Machado, 31058 Toulouse cedex, France - morgane-dachary@orange.fr

\section{CATHERINE DENIEL}

Clermont Université, Université Blaise Pascal, Laboratoire Magmas et Volcans, BP 10448, 63000 Clermont-Ferrand - CNRS, UMR 6524, LMV et IRD, R 163, LMV, 63038 Clermont-Ferrand, France c.deniel@opgc.univ-bpclermont.fr

\section{FRÉDÉRIC PLASSARD}

UMR 5199, PACEA-Université Bordeaux 1, avenue des Facultés, 33400 Talence, France frederic.plassard@wanadoo.fr 


\section{PIERRE BOIVIN}

Clermont Université, Université Blaise Pascal, Laboratoire Magmas et Volcans, BP 10448, 63000 Clermont-Ferrand - CNRS, UMR 6524, LMV et IRD, R 163, LMV, 63038 Clermont-Ferrand, France p.boivin@opgc.univ-bpclermont.fr

\section{JEAN-LUC DEVIDAL}

Clermont Université, Université Blaise Pascal, Laboratoire Magmas et Volcans, BP 10448, 63000 Clermont-Ferrand - CNRS, UMR 6524, LMV et IRD, R 163, LMV, 63038 Clermont-Ferrand, France j.l.devidal@opgc.univ-bpclermont.fr 